Obrazotvorche mystetstvo, 2018 - Obrazotvorche mystetstvo. Navchalna prohrama dlia zahalnoosvitnikh navchalnykh zakladiv 1-4 klasy. Rezhym dostupu: https://mon.gov.ua/storage/app/media/zagalna\%20serednya/programy-1-4-klas/9-obrazotvorchemistecztvo-1-4-klas.doc

Osvitni tekhnolohii, 2003 - Osvitni tekhnolohii: navch.-metod. posibn / O. M. Pekhota, A. Z. Kiktenko, O. M. Liubarska ta in.; za red. O. M. Piekhoty. - K. : Vydavnytstvo A.S.K., 2003. - 255 s.

Pichkur, 2000 - Pichkur M. O. Formuvannia profesiinoi kultury maibutnoho vchytelia obrazotvorchoho mystetstva (na materiali kompozytsii): avtoref. dys...kand. ped. nauk: 13.00.04 / M. O. Pichkur ; In-t pedahohiky i psykholohii prof. osvity APN Ukrainy. - K., 2000. - 20 s.

Pro zatverdzhennia..., 2018 - Pro zatverdzhennia Derzhavnoho standartu pochatkovoi osvity. Rezhym dostupu: https://www.kmu.gov.ua/ua/npas/pro-zatverdzhennya-derzhavnogo-standartu-pochatkovoyi-osviti

Sysoieva, 2006 - Sysoieva S. O. Osnovy pedahohichnoi tvorchosti: Pidruchnyk. - K.: Milenium, 2006. - 344 s.

Muzyka, 2011 - Muzyka O. Ya. Rozvytok tvorchykh zdibnostei maibutnikh uchyteliv obrazotvorchoho mystetstva v protsesi vyvchennia fakhovykh dystsyplin : dys. ... kan. ped. nauk : 13.00.04 / Muzyka Olha Yanoshivna ; Umanskyi derzhavnyi un-t imeni Pavla Tychyny. - Uman, 2011. - 300 s.

\section{УДК 373.3.016:81.161.2}

\section{Тетяна Форостюк,} кандидат педагогічних наук, доцент кафедри педагогіки, теорії та методики початкової освіти ДВНЗ «ПереяславХмельницький державний педагогічний університет імені Григорія Сковороди».

\section{DOI 10.31470/2308-5126-2019-45-2-147-153}

\author{
Tetiana Forostyuk,
}

Ph.D. in Pedagogy, Associate Professor of the Department of Pedagogy, Theory and Methodology of Primary Education SHEI «Pereiaslav-Khmelnytskyi Hryhorii Skovoroda State Pedagogical University».

E-mail: forostiuk7@gmail.com

ORCID 0000-0002-9716-3265

\title{
ФОРМУВАННЯ КОМУНІКАТИВНОЇ КОМПЕТЕНТНОСТІ В МАЙБУТНІХ УЧИТЕЛІВ СУЧАСНОӤ ПОЧАТКОВОӤ ШКОЛИ В ПРОЦЕСІ ФАХОВОЇ ПІДГОТОВКИ
}

У статті висвітлено проблему формування комунікативної компетентності в майбутніх учителів початкової школи в прочесі фахової підготовки. Проаналізовано наукові праці з проблеми. Узагальнено сучасні підходи до розв 'язання актуальної проблеми сьогодення.

У статті обтрунтовується думка про те, щчо підготовка майбутнього фахівия початкової школи буде найефективнішою, якщо здійснювати ї̈ з урахуванням компетентнісного підходу та особливостями формування комунікативної компетенції. Комунікативно-діяльнісний підхід у процесі фахової підготовки майбутніх учителів початкової школи сприяє ефективному формуванню комунікативної компетентності студентів, які в майбутньому зможуть формувати комунікативну компетентність учнів, готовність спілкуватися українською мовою в повсякденному спілкуванні, любов до рідного слова, інтерес $і$ повагу до історичного минулого украӥнського народу, до украӥнської мови.

Досліджено сутність поняття «комунікативна компетентність», а також «комунікативна компетенція». Розглянуто визначення понять у науковій літературі.

Розкрито й доведено необхідність використання ефективних методів, засобів і прийомів у процесі фахової підготовки майбутніх учителів початкової школи, зокрема на уроках української мови. Здійснено спробу узагальнити умови формування комунікативної компетентності в майбутніх учителів початкової школи в процесі фахової підготовки. Проаналізовано педагогічний досвід. Звертається увага на важливість упровадження в практику підготовки майбутнього вчителя інноваційних технологій, методів, прийомів, які сприятимуть формуванню комунікативної компетентності майбутніх учителів початкової школи. Пропонуються иікаві вправи та завдання, зокрема з української мови, які будуть ефективними під час формування комунікативної компетентності в майбутніх учителів початкової школи.

Розглядається вербальне спілкування та невербальні засоби спілкування, етикет у спілкуванні. Звертається увага на можливі помилки в мовленні та спілкуванні. Пропонуються иляхи формування комунікативної компетентності майбутнього вчителя та учнів початкової школи, щуо сприятимуть ефективній комунікації.

Ключові слова: комунікативна компетентність, майбутні вчителі, початкова школа, фахова підготовка, формування. 
The The article deals with the problem of formation of communicative competence in future teachers of elementary school in the process of professional training. The author analyzes scientific works on the problem. The modern approaches to solving the actual problem of the present are generalized.

The article substantiates the opinion that the training of a future specialist in elementary school will be the most effective if implemented in the light of a competent approach and peculiarities of the formation of communicative competence. The communicative-activity approach in the process of professional training of future primary school teachers contributes to the effective formation of the communicative competence of students, who in the future will be able to form the communicative competence of students, readiness to communicate in Ukrainian in everyday communication, love to the native word, interest and respect to the historical past of the Ukrainian people, to the Ukrainian language.

The author explores the essence of the concept of «communicative competence», as well as «communicative competence». The definition of concepts in the scientific literature is considered.

The necessity of using effective methods, tools and techniques in the process of professional training of future elementary school teachers, in particular Ukrainian language lessons, has been revealed and proved. The author has made an attempt to generalize the conditions for the formation of communicative competence in future elementary school teachers in the process of professional training. The pedagogical experience is analyzed. The attention is drawn to the importance of introducing into practice of training of the future teacher innovative technologies, methods and techniques that will promote the formation of communicative competence of future elementary school teachers. The interesting exercises and tasks are offered, in particular from the Ukrainian language, which will be effective in developing communicative competence in future elementary school teachers.

The verbal communication and nonverbal means of communication, etiquette in communication are considered.The attention is drawn to possible mistakes in speech and communication. The ways of formation of communicative competence of the future teacher and elementary school students, which will promote effective communication, are offered.

Keywords: communicative competence, future teachers, elementary school, vocational training, formation.

Постановка проблеми. Формування комунікативної компетентності в майбутніх учителів сучасної початкової школи - актуальна проблема сьогодення. Адже вчитель початкової школи закладає фундамент любові та поваги до української мови, а тому сам має досконало іiі знати, практично володіти всіма засобами мови, дбати про чистоту та правильність власного мовлення. А формування комунікативної компетентності студентів, які в майбутньому працюватимуть у сучасній школі - це важливе завдання, яке є актуальним у зв'язку зі змінами в сучасній освіті та Україні, потребою суспільства в компетентних фахівцях, здатних організувати процес спілкування.

Сьогодні актуальною є зазначена проблема, адже від іï розв'язання залежить, чи зможуть студенти в майбутньому якісно сформувати комунікативну компетентність учнів. Відомо, що тільки вчитель, який досконало сам володіє мовленням, зможе сприяти формуванню комунікативної компетентності учнів. До того ж володіння майбутніми вчителями й учнями комунікативною компетентністю є життєвою необхідністю.

Аналіз останніх досліджень $\boldsymbol{i}$ публікацій свідчить, що проблема формування комунікативної компетентності в майбутніх учителів сучасної початкової школи в процесі фахової підготовки була в полі зору багатьох науковців. А тому поняття комунікативної компетентності вивчалося педагогами, психологами, методистами, лінгвістами, психолінгвістами. Це питання грунтовно вивчали Л. Виготський, О. Савченко, О. Леонтьєв, М. Вашуленко, Л. Мацько, А. Богуш, Є. Божович, Г. Шелехова, В. Мельничайко, М. Пентилюк, Л. Щерба та інші.

Мета написання стаmmi - розкрити сутність поняття «формування комунікативної компетентності» майбутнього вчителя сучасної початкової школи в процесі фахової підготовки, а також проаналізувати сучасний досвід вирішення проблеми, наукові підходи щодо їі розв’язання. 
Виклад основного матеріалу. В умовах сучасних змін в освіті та реальних потреб суспільства в оновленні існуючих підходів до навчання та формування особистості людини, особливої актуальності набуває проблема фахової підготовки сучасного вчителя початкової школи, зокрема формування його комунікативної компетентності. Відомо, що компетентнісний підхід у навчанні передбачає спрямованість освіти на формування предметних i ключових компетенцій [Формування предметних...,2014: с. 104].

Реалізація компетентнісного підходу $є$ важливим завданням сучасної української школи, а також закладів вищої освіти, які готують фахівців, здатних упроваджувати інноваційні прогресивні ідеї в практику. Результатом роботи вчителя мають бути сформовані ключові компетентності. Саме тому майбутній фахівець має бути готовим до організації роботи в школі, до оновлення навчально-методичного забезпечення освітнього процесу, запровадження ефективних методів, прийомів навчання, форм організації освітньої діяльності, до реалізації компетентнісного підходу в навчанні [Формування предметних...,2014: с. 104].

У Державному стандарті звертається увага на ключові компетентності, які мають бути результатом навчання. Зокрема, до таких обов'язкових важливих компетентностей належить вільне володіння українською мовою, тобто вміння письмово та усно висловлювати свої думки, почуття; розуміння ролі мови; здатність і бажання активно користуватися мовними засобами в різних життєвих ситуаціях [Про затвердження..., 2018: с. 1-2].

Як зазначається в Державному стандарті, формування комунікативної компетентності $є$ метою вивчення української мови та літератури. Саме ці предмети мають змогу забезпечити формування комунікативної компетентності. Також у Державному стандарті звернено увагу на важливість формування читацької компетентності, на розвиток людини засобами різних видів мовленнєвої діяльності, на здатність спілкуватися українською мовою, на збагачення чуттєвого досвіду, розвиток мовленнєво-творчих здібностей [Про затвердження..., 2018: с. 4].

У Державному стандарті звертається увага на те, які ж результати мають бути, якщо сформовано комунікативну компетентність. Тоді людина зможе взаємодіяти усно й письмово 3 іншими, сприйматиме й використовуватиме інформацію в різних комунікативних ситуаціях, зможе аналізувати та критично оцінювати отриману інформацію, вільно висловлюватиме думки, зможе досліджувати індивідуальне мовлення 3 метою власної мовної творчості, буде дотримуватися норм літературної мови [Про затвердження..., 2018: с. 4].

Як свідчить аналіз джерел, науковці виділяють компетенцію та компетентність. Також у науковій літературі немає єдиної точки зору щодо розуміння сутності цих понять. Цікавою $\epsilon$ думка вчених, які вважають «компетенцію» нормою, вимогою, метою, а «компетентність» трактують як особистісну, як результат оволодіння певною компетенцією [Формування предметних...,2014: с. 7].

M. Вашуленко пропонує таке визначення сутності «комунікативна компетентність»: «здатність успішно користуватися мовою в процесі спілкування, пізнання навколишнього світу, вирішення життєво важливих завдань» [Формування предметних..., 2014: с. 68].

А. Прищепа, О. Божович, Г. Шелехова, К. Пономарьова, Л. Мацько та інші доводять, що комунікативна компетентність - це не лише навчальна мета, а й 
важлива умова оволодіння знаннями на різних рівнях освіти [Формування предметних..., 2014: с. 24].

Щоб сформувати комунікативну компетентність, як зазначає К. Пономарьова, варто сформувати здатність і готовність до спілкування 3 іншими людьми. 3 цією метою потрібно в процесі навчання створити всі умови для оволодіння особистістю різними видами мовленнєвої діяльності: говорінням, аудіюванням, читанням, письмом, а також мовою як засобом спілкування [Формування предметних..., 2014: с. 104].

Компетентнісний підхід у навчанні української мови, на думку К. Пономарьової, сприяє тому, що мова буде не лише засобом спілкування, а й пізнання культури народу, засобом підвищення інтелектуального й культурного рівнів людини [Формування предметних..., 2014: с. 189].

Тобто, за допомогою мови відбувається виховання мовної особистості, суб'єкта національної культури. У мові можна простежити всі аспекти життя народу, адже минуле, сучасна культура, усі цінності, норми, духовність фіксуються в мові й передаються наступним поколінням [Формування предметних..., 2014: с. 189].

А тому майбутній учитель початкової школи має бути мовною особистістю, зі сформованою комунікативною компетентністю. Соціокультурний підхід до вивчення української мови передбачає іiі вивчення крізь призму національної культури, адже мова є не лише засобом спілкування, а й джерелом інформації про український народ і світ у цілому [Формування предметних..., 2014: с. 189].

Майбутній учитель початкової школи має бути творчою і комунікативно компетентною особистістю, здатною самостійно та з інтересом здобувати знання 3 різних джерел, творчо використовувати всі засоби української мови в процесі спілкування, життєтворчості та самореалізації. 3 цією метою в процесі фахової підготовки треба створити необхідні умови для формування комунікативної компетентності, для саморозвитку та самопізнання, а також атмосферу творчості, взаємодії, приязні, інтересу під час практичної діяльності.

Важливим є усвідомлення важливості формування комунікативної компетентності, розуміння, що вчитель має бути людиною, яка досконало володіє мовними засобами. Адже головним професійним «інструментом» учителя $є$ його слово [Формування предметних..., 2014: c. 134]. А практика свідчить, що для молодших школярів учитель $є$ зразком, зокрема правильного мовлення, спілкування, а тому є «Першовчителем рідної мови» [Формування предметних..., 2014: с. 134].

М. Вашуленко наголошує, що комунікативна функція $\epsilon$ нині однією 3 найважливіших функцій спілкування та охоплює форми й засоби обміну та передавання інформації, тому вчитель початкової школи має допомогти учням усвідомити, що вони повинні говорити й писати зрозуміло для інших, а також знати, що саме, де, коли і як говорити в різних ситуаціях. Науковець зазначає, що вчитель у доступній формі, практично має вчити дітей користуватися мовними засобами в повсякденному житті [Формування предметних..., 2014: c. 135]. Адже, як наголошує М. Вашуленко, щоб користуватися мовою як засобом спілкування, крім граматичних правил, також варто знати ситуативні, контекстуальні, соціальні правила [Формування предметних..., 2014: с. 135].

Майбутній учитель початкової школи, як зазначає М. Вашуленко, має знати показники сформованості комунікативної компетентності учнів, тобто вміння та практичний досвід, а також сам повинен їх мати. Зокрема, це вміння практично користуватися лексичним і граматичним скарбами мови в процесі спілкування. 
Мотивувати своє спілкування - це теж важливе вміння. Учитель і учні мають вміти обирати тему для спілкування. Важливими також є такі вміння: розуміти та враховувати особливості конкретної ситуації спілкування, уміння налагоджувати контакт з іншою людиною, аналізувати та створювати тексти різних стилів і жанрів, ставити запитання та відповідати на них, триматися та виступати перед аудиторією, формулювати та обгрунтовувати власну позицію щодо певного питання, узагальнювати та робити висновки, бути відповідальним за сказане, аналізувати та критично оцінювати своє мовлення та мовлення інших. На думку, М. Вашуленка, це важливі показники сформованої комунікативної компетентності. Їх має знати майбутній учитель початкової школи. Для формування власної комунікативної компетентності має приділяти цьому значну увагу [Формування предметних..., 2014 : c. 134].

У Державному стандарті початкової освіти теж зазначається, що треба навчити дітей користуватися мовою практично [Про затвердження..., 2018: c. 1215]. Адже оволодіння комунікативною компетентністю $є$ важливою потребою що «виявляється у здатності успішно користуватися мовою в процесі спілкування, пізнання навколишнього світу, вирішення життєво важливих завдань» [Про затвердження..., 2018: с. 12-15].

Адже учні мають навчитися практично користуватися мовою. До того ж учитель у процесі виконання практичних завдань має приділяти увагу комунікативній функції мови.

Завдання мають бути практичними: побудувати та вдосконалити висловлювання, побудувати діалог, придумати казку, робота зі словником, редагування речень, пояснити лексичне значення нових слів та ін. Саме в процесі вирішення життєвих мовленнєвих ситуацій, під час реалізації комунікативнодіяльнісного підходу формуватимуться комунікативні вміння учнів, це сприятиме створенню умов для практичного вивчення мови, ознайомлення зі звуками, словом, найуживанішою лексикою, реченням, текстом та ін.; а також вироблятимуться вміння застосовувати знання та вміння в процесі користування мовою як засобом спілкування, впливу,пізнання, сприйняття.

Підготовка майбутнього фахівця початкової школи буде ефективною, якщо здійснювати іï 3 урахуванням компетентнісного підходу та особливостями формування комунікативної компетенції. Комунікативно-діяльнісний підхід у процесі професійної підготовки вчителів сприяє ефективному формуванню комунікативної компетентності студентів.

М. Вашуленко наголошує, що студенти мають опанувати комунікативнодіяльнісний підхід, який сьогодні використовується в сучасній школі [Формування предметних..., 2014: c. 137]. Науковець радить студентам самостійно виконати вправи $з$ підручників для початкової школи, орієнтовані на спостереження, а в процесі промовляння скоромовок, потішок та інших творів звернути увагу на виражальні засоби, зокрема, тон, силу голосу, швидкість мовлення. Варто пропонувати учням створювати власні висловлювання, а також діалог і полілог. Ці ж завдання можна запропонувати студентам на практичних заняттях [Формування предметних..., 2014: с. 137].

Науковці вважають, щоб правильно спілкуватися й досягати мети, треба знати про мовні й немовні засоби спілкування, про етикет у спілкуванні, про невербальні засоби, уміти застосовувати знання практично [Радевич-Винницьькй, 2006: c. 21-22]. 
Адже спілкування буває вербальним, мовним, тобто словесним. Інший вид спілкування - невербальне, здійснюється за допомогою міміки, жестів, погляду, умовних знаків тощо. Можуть реалізовуватись одночасно [Радевич-Винницький, 2006: c. 15].

Майбутньому вчителю початкової школи варто звернути на такі типові помилки, яких варто уникати, а також на правильні варіанти вживання слів, на які звертає увагу Я. Радевич-Винницький. Науковець говорить, що неправильно вимовляти кінцеві дзвінкі приголосні глухо (хлі[п], а треба хлі[б]). Правильно наголошувати слова: новий (2 склад), одинадцять (3 склад), колесо (1 склад), різновид (2 склад), середина (2 склад).

Правильно: прізвища на -ко, -енко, які належать особам чоловічої статі, відмінювати як іменники 2 відміни: виступ Петренка.

Правильно: після числівників 2, 3, 4 ставити іменник чоловічого роду у формі множини: два хлопці, два митці. Неправильно: два хлопця.

Неправильно: Сергіє, Віталіє. Так правильно вживаємо жіночі імена на -я: Даріє, Маріє. Правильно вживати чоловічі імена на -ій у кличному відмінку так: Сергію, Віталію [Радевич-Винницький, 2006: с. 260-267].

Я. Радевич-Винницький наголошує, що вміння слухати $\epsilon$ критерієм комунікабельності. Це «мистецтво, без якого неможливо бути добрим фахівцем, керівником, просто шанованою людиною» [Радевич-Винницький, 2006: с. 273].

А тому майбутньому вчителю початкової школи варто прислухатися до порад Я. Радевича-Винницького: треба бути доброзичливим до учнів; не перетворювати розмову на допит; спостерігати, як людина реагує на сказане; не поспішати $з$ висновками; варто говорити про те, що людину цікавить; необхідно керувати своїми почуттями («не говорити відразу, якщо ти роздратований»); не відповідати грубощами на грубощі; говорити спокійно, ввічливо, переконливо; не говорити багато про себе; говорити про те, що знаєш; не розголошувати довіреної інформації, службових таємниць тощо; 3 повагою ставитися до чужого часу, уваги; не поширювати плітки; не повчати, не виправляти помилок у мовленні колег, якщо вони про це не просять; ставити себе на місце партнера під час спілкування [Радевич-Винницький, 2006: с. 273-278].

Науковці стверджують, щоб сформувати комунікабельного, ініціативного, творчого, активного, відповідального, упевненого вчителя, який уміє працювати в колективі, володіє сформованою комунікативною компетентністю, є справедливим, потрібно у закладах вищої освіти застосовувати інноваційні методи й форми, вітчизняний і зарубіжний педагогічний досвід [Формування предметних..., 2014: c. 173].

На думку І. Дичківської, важливою є готовність учителя до проведення уроків, зокрема української мови, у початковій школі. Така готовність, на думку I. Дичківської, виробляється i $є$ результатом щоденної підготовки, а також самоосвіти та самовиховання людини [Дичківська, 2004: с. 276].

Важливою є мотивація до роботи, прагнення до вдосконалення, роботи над собою. На думку вчених, майбутньому вчителю початкової школи важливо здійснювати щоденну практичну підготовку до роботи в школі, а також підвищувати рівень теоретичних знань [Освітні технології, 2003: с. 118].

Як свідчить досвід, упровадження ефективних методичних засобів, методів, прийомів, технологій сприяє формуванню комунікативної компетентності особистості. Варто на практичних заняттях пропонувати студентам цікаву роботу, 
створювати атмосферу пошуку, активізувати внутрішню потребу в самовдосконаленні, розвивати самостійність як засіб саморозвитку [Освітні технологіï, 2003: с. 122].

Висновки. Тобто, ми з'ясували, що проблема має теоретичну базу. Але питання формування комунікативної компетентності майбутнього вчителя початкової школи потребує подальшого розгляду.

\section{ЛІТЕРАТУРА}

Дичківська, 2004 - Дичківська І. М. Інноваційні педагогічні технології: Навчальний посібник. К. : Академвидав, 2004. 352 с.

Освітні технологї̈, 2003 - Освітні технології: навч.-метод. посібн. / О. М. Пехота, А. 3. Кіктенко, О. М. Любарська та ін.; за ред. О. М. Пехоти. К. : Видавництво А.С.К., 2003. 255 с.

Про затвердження..., 2018 - Про затвердження Державного стандарту початкової освіти. Режим доступу: https://www.kmu.gov.ua/ua/npas/pro-zatverdzhennya-derzhavnogo-standartu-pochatkovoyi-osviti

Радевич-Винницький, 2006 - Радевич-Винницький Я. Етикет і культура спілкування: Навч. посіб. К. : Знання, 2006. $291 \mathrm{c}$.

Формування предметних...,2014 - Формування предметних компетентностей в учнів початкової школи: монографія / Н. М. Бібік, М. С. Вашуленко, В. О. Мартиненко та інші. К. : Педагогічна думка, 2014. $346 \mathrm{c}$.

\section{REFERENCES}

Dychkivska, 2004 - Dychkivska I. M. Innovatsiini pedahohichni tekhnolohii: Navchalnyi posibnyk. K. : Akademvydav, 2004. $352 \mathrm{~s}$.

Osvitni tekhnolohii, 2003 - Osvitni tekhnolohii: navch.-metod. posibn. / O. M. Pekhota, A. Z. Kiktenko, O. M. Liubarska ta in.; za red. O. M. Piekhoty. K. : Vydavnytstvo A.S.K., 2003. 255 s.

Pro zatverdzhennia..., 2018 - Pro zatverdzhennia Derzhavnoho standartu pochatkovoi osvity. Rezhym dostupu: https://www.kmu.gov.ua/ua/npas/pro-zatverdzhennya-derzhavnogo-standartu-pochatkovoyi-osviti

Radevych-Vynnytskyi, 2006 - Radevych-Vynnytskyi Ya. Etyket i kultura spilkuvannia: Navch. posib. K. : Znannia, 2006. $291 \mathrm{~s}$.

Formuvannia predmetnykh..., 2014 - Formuvannia predmetnykh kompetentnostei v uchniv pochatkovoi shkoly: monohrafiia / N. M. Bibik, M. S. Vashulenko, V. O. Martynenko ta inshi. K. : Pedahohichna dumka, 2014. $346 \mathrm{~s}$.

\section{УДК 911.3:33:001.82}

Борис Чернов, кандидат педагогічних наук, професор, завідувач кафедри географії, екології та методики навчання

ДВНЗ «Переяслав-Хмельнииький державний педагогічний університет імені Григорія Сковороди».

\section{DOI 10.31470/2308-5126-2019-45-2-153-162}

E-mail: olimp-geograf@ukr.net

ORCID 0000-0002-5376-0412

\section{METHODOLOGICAL BASIS OF ECONOMIC GEOGRAPHY}

Сьогодні глобальні економічні зміни вимагають вирімувати багато питань, пов'язаних не тільки 3 удосконаленням новітніх технологій в промисловості, сільському господарстві, але й в соціальній сфері розв'язанні проблем внутрішніх $і$ зовнішніх міграцій населення. Ці питання до 60-х рр. ХХ ст. входили складовою частиною до економічної географії. Економічна географія у ией період досягла значних успіхів, була визнана не тільки у намій країні, а й за рубежем. Свідченням иьього тріумфу були міжнародні наукові конферениії та численні публікачії. Після тривалої дискусії економічна географія як окрема самостійна наука перестала існувати. Тому постала проблема з 'ясування сучасного статусу економічної географї в системі географічних наук, оскільки ия наука, на думку окремих географів, втратила самостійність і стала певним 